\title{
Penyuluhan Peningkatkan Kualitas Produk Pada Pengrajin Genteng Di Desa Gulun Kabupaten Magetan
}

\author{
Bambang Suyono ${ }^{1}$, Hery Hermawan ${ }^{2}$ \\ ${ }^{I}$ Fakultas Ekonomi, Universitas Merdeka Madiun, Jl. Serayu No.79, Madiun, 63133 \\ E-mail: bambangsuyono@unmer-madiun.ac.id \\ ${ }^{2}$ Fakultas Ekonomi, Universitas Merdeka Madiun, Jl. Serayu No.79, Madiun, 63133 \\ E-mail: heryhermawan@unmer-madiun.ac.id
}

\begin{abstract}
The lack of facilities plays an important role in realizing a clean and healthy life, but it is not an obstacle for the participants and other school members of SDK Santo Bavo to be able to habituate their daily healthy lifestyle. The results of the initial survey conducted by SDK Santo Bavo students had never been given any education or counseling on the importance of clean and healthy living habits. Based on this, it is necessary to do it through counseling and training on PHBS (Healthy Day-to-Life Behavior) for students in and other residents in TKK and SDK Santo Bavo. The activity is carried out through counseling and training on how to wash hands properly with boiled water of betel leaf as a substitute for soap which has antibacterial properties. Online counseling activities through instructional videos have succeeded in increasing partners' knowledge about making green betel leaf (Piper betle L) boiled water which has antibacterial properties and steps on how to wash with boiled green betel leaf water as a substitute for soap (CTPS) which is good and correct.
\end{abstract}

Keywords - : daily healthy behavior, green betel, antibacterial, learning videos.

\section{PENDAHULUAN}

Pesatnya pembangunan pada dunia industri meningkatkan persaingan yang terjadi antar perusahaan dalam menghasilkan produk-produk berkualitas dengan harga yang cukup bersaing. Menghadapi persaingan usaha yang cukup ketat, perusahaan harus memiliki strategi dan metode yang tepat sehingga produknya dapat tetap bersaing dan tetap menghasilkan keuntungan sesuai dengan rencana yang telah ditetapkan.

Sektor Usaha Kecil Menengah (UKM) merupakan salah satu industri yang turut bersaing dalam memajukan perekonomian di Indonesia. Dalam pembangunan ekonomi di Indonesia UKM selalu digambarkan sebagai sektor yang memiliki peranan penting karena sebagian besar penduduk Indonesia hidup dalam kegiatan usaha kecil baik di sektor tradisional maupun modern. Usaha Kecil dan Menengah (UKM) mempunyai peran yang strategis dalam pembangunan ekonomi nasional, karena selain berperan dalam pertumbuhan ekonomi dan penyerapan tenaga kerja juga berperan dalam perindustrian hasil-hasil pembangunan.

Banyaknya jumlah UKM secara otomatis akan meningkatkan persaingan yang semakin ketat. Peningkatan jumlah unit usaha ini juga diikuti dengan bertambahnya jumlah tenaga kerja. Kedua hal tersebut tentunya akan membawa ke dalam suatu persaingan bisnis yang kompleks. Maka dari itu, UKM harus mempunyai strategi bersaing diantaranya adalah keunggulan mutu produk yang tinggi serta harga yang bersaing. Keunggulan mutu produk terlihat dari penggunaan mesin produksi yang modern, dan bahan baku yang berkualitas.

Atap bangunan berguna sebagai payung yang melindungi bangunan di bawahnya dari pengaruh panas matahari, hempasan air hujan, dan tiupan angin (Rudy Gunawan, 2005). Ada beberapa bahan yang biasa digunakan sebagai atap rumah. Genteng adalah salah satu jenisnya. Genteng telah menjadi komponen utama dari bangunan sepanjang sejarah peradaban manusia. Atap genteng dapat ditemukan di hampir semua iklim atau wilayah dan dapat menahan beberapa kondisi cuaca yang paling berbahaya. Genteng di Indonesia umumnya berbahan tanah liat. Material dasar ini mudah didapatkan, hingga banyak orang menjual dan menggunakan genteng tanah liat.

Upaya peningkatan kualitas dan mutu genteng dari tanah liat terus diupayakan seiring dengan munculnya berbagai jenis genteng yang berfungsi sebagai atap misalnya: asbes, seng, genteng beton dari industri besar dan lain-lain. Genteng tanah liat masih menjadi pilihan konsumen untuk bahan finishing atap rumah, selain itu harga tanah liat terjangkau oleh konsumen. Hal yang perlu diperhatikan dalam pemilihan penutup atap yang baik adalah awet dan tahan lama dalam menghadapi cuaca ekstrim. Dengan adanya bangun-bangunan yang banyak memerlukan atap yang kualitasnya kuat, rapat dan kedap air, maka genteng tanah liat merupakan salah satu pilihan. Kelemahan dari genteng tanah liat adalah jika digunakan dalam jangka panjang akan mengendapnya lumut dipermukaan genteng. Hal ini dapat diperbaiki lualitasnya melalui penggunaan mesin dengan tehnologi modern dan campuran bahan baku untuk mencegah munculnya lumut pada genteng tanah liat bila digunakan dalam jangka panjang. Walaupun demikian genteng tanah liat masih bersaing kuat dipasaran dengan genteng-genteng buatan pabrik industriindustri besar dan menengah.

Desa Gulun dikenal dengan Sentra industri kerajinan genteng. Mayoritas penduduk desa Gulun bermata pencaharian sebagai pengrajin genteng, Kerajinan ini bernama Genteng Winong (mencakup 2 desa yaitu Desa Gulun dan Desa 
Website : http://dayamas.unmermadiun.ac.id/index.php/dayamas

Tanjungsepreh). Mengenai industri kerajinan genteng ini, Desa Gulun bisa di bilang sebagai leader untuk sektor industri ini. Karena sejak tahu 1920-an, industri ini mulai dikenal di masyarakat desa ini. Tetapi mulai dikerjakan secara profesional sebagai bentuk usaha baku sekitar tahun 1970-an.

Di era 1990-an, industri genteng di desa Gulun ini mulai menjadi primadona sebagai sektor usaha yang menjanjikan, bahkan di era itu hanya desa-desa di sekitar yang ikut menggeluti bidang usaha ini. Tidak hanya itu, tingkat pengangguran nyaris tidak ada karena adanya industri genteng ini.

Gulun adalah sebuah nama desa di wilayah Kecamatan Maospati, Kabupaten Magetan, Provinsi Jawa Timur. Secara administratif Desa Gulun berbatasan dengan Desa Tanjung Sepreh di sebelah barat, Desa Mantren di sebelah Utara, Desa Malang di sebelah Timur dan Desa Sugihwaras di sebelah selatan.

Desa ini dibentuk kurang lebih abad ke-18 pada masa perang Diponegoro. Dimana salah satu perwira dari prajurit Diponegaran (Singo Wijoyo) yang terdesak melarikan diri bersama rombongannya di daerah ini, untuk kemudian membuka suatu pemukiman baru, yang terus berkembang sampai sekarang nama Desa Gulun, menurut penuturan orang-orang tua diambil dari nama sebuah pohon. Sampai saat ini jenis pohon ini masih bisa dijumpai di desa tersebut.

Agar industri genteng ini dapat bertahan dan berkembang di tengah-tengah persaingan usaha yang ketat di era globalisasi, perlu adanya pemberdayaan yang berkelanjutan agar dapat mempertahankan eksistensi usahanya. Oleh karena itu perlu adanya sentuhan teknologi dalam proses produksi genteng sehingga kualitas dan kapasitas produksi dapat memenuhi tuntutan konsumen.

Dalam menentukan persoalan prioritas yang disepakati untuk diselesaikan selama pelaksanaan kegiatan Iptek bagi Masyarakat ini meliputi: (1) Pemahaman tentang perlunya pengelolaan dan pemberdayaan manajemen usaha yang baik dan sehat, (2) Melakukan pelatihan manajemen usaha yang professional; (3) Melakukan pendampingan dan pemasaran hasil produksi; (4) Perlunya penggunaan mesin produksi yang mampu memenuhi keinginan pasar.

\section{METODE PELAKSANAAN DAN EVALUASI}

Kegiatan yang direncanakan akan diimplementasikan dengan menggunakan metode-metode yang mencakup :

1. Penyuluhan mengenai : (a) Kewirausahaan dan kiat sukses berwirusaha; (b) Manajemen usaha, yang mencakup manajemen keuangan (perhitungan harga pokok produksi dan penentuan harga jual) dan manajemen pemasaran; dan (c) Pemahaman akan manfaat iptek (penggunaan mesin produksi yang modern dan manajemen usaha yang baik dan profesional) dalam pengembangan usaha.

2. Pelatihan ketrampilan, yaitu pelatihan terkait dengan penggunaan mesin produksi dan manajemen usaha yang baik dan professional.

3. Pendampingan aktivitas produksi dan pemasaran

Pendampingan dilakukan selain pada aspek produksi juga pada aspek pemasaran produk dan manajemen usaha. Dari aspek pemasaran, mitra akan didampingi mencari akses pasar, melalui media online (facebook dan instagram), melalui koperasi Kabupaten Magetan serta bekerja sama dengan Dinas Perindustrian dan Perdagangan Kabupaten Magetan.

4. Penggunaan teknologi untuk pelatihan yang benar-benar dapat dilakukan oleh masyarakat dengan potensi yang tersedia, murah dan mudah dilaksanakan.

5. Partisipasi mitra dalam pelaksanaan kegiatan program ini meliputi:

a. Merencanakan jadwal dan tempat kegiatan penyuluhan maupun pelatihan

b. Menyediakan bahan dan alat-alat peraga untuk pelatihan

c. Menyediakan waktu dan tenaga selama pelaksanaan program

d. Menyiapkan unit pengelolaan keberlanjutan program

e. Membantu mengupayakan kerjasama dalam pemasaran produk.

\section{III.HASIL DAN PEMBAHASAN}

\section{A. Tahapan Kegiatan Pengabdian Masyarakat}

1. Pada tahap awal kami melakukan koordinasi dengan Kantor Kecamatan Maospati Kabupaten Magetan terkait dengan pengurusan perijinan kegiatan pengabdian masyarakat.

2. Selanjutnya kami melakukan koordinasi dengan Kepala Desa Gulun Kecamatan Maospati Kabupaten Magetan.

3. Setelah melakukan koordinasi dengan pihak Kepala Desa selanjut melakukan koordinasi dan kerjasama dengan pihak mitra yaitu Kelompok Pengrajin Genteng Singo Negoro dan Intan.

\section{B. Hasil Kegiatan}

Hasil kegiatan yang diperoleh dari kegiatan pengabdian kepada masyarakat ini adalah sebagai berikut:

1. Mitra dapat meningkatkan kualitas atau mutu produk genteng di Desa Gulun, sehingga mampu bersaing dengan produk pesaing.

2. Mitra mampu mengimplementasikan strategi pemasaran produk genteng secara efektif.

3. Mitra dapat menghitung harga produk genteng yang kompetitif dan mampu bersaing dengan harga produk pesaing. 
Website : http://dayamas.unmermadiun.ac.id/index.php/dayamas

4. Mitra mampu meningkatkan laba usaha secara signifikan.

\section{Pembahasan}

Pelaksanaan kegiatan pengabdian kepada masyarakat dengan judul IbM Pengrajin Genteng Desa Gulun Kecamatan Maospati Kabupaten Magetan, ini sebagai upaya untuk membantu meningkatkan kualitas dan kuantitas produksi genteng yang pada akhirnya diharapkan dapat meningkatkan pendapatan para pengrajin genteng. Pengabdian masayrakat ini terdiri dari 4 (empat) kegiatan pokok yaitu :

1. Melihat dan mengevaluasi serta menginventarisasi permasalahan dan peralatan yang ada serta cara kerja dalam industri kecil kerajinan genteng kemudian hasil dari kegiatan dilapangan tersebut dibandingkan dengan literatur/referensi.

2. Mempelajari proses produksi kerajinan genteng. Menentukan sistem kerja alat. Mengumpulkan dan mencatat serta mempelajari data yang diperlukan. Membuat konsep alat pencetak/pengepres genteng yang akan dibuat serta memantau jalannya pembuatan produk.

3. Merencanakan, membuat dan mencoba serta melatih cara penggunaan alat pencetak/pengepres genteng.

4. Memberikan saran dan petunjuk di lapangan pada pengrajin yang mengoperasikan alat (operator) sehingga diperoleh cara menggunakan alat pencetak/pengepres genteng dengan efektif dan efisien.

Pengrajin genteng yang berada di desa Gulun, secara umum para pengrajin ini masih menggunakan alat pencetak/pengepres genteng yang manual. Ukuran genteng yang dihasilkan $30 \mathrm{~cm} \times 22 \mathrm{~cm} \times 1.5 \mathrm{~cm}$. Proses pengepresan genteng dilakukan dengan cara menekan dengan kaki.

Permasalahan yang muncul tersebut diupayakan diselesaikan dengan solusi yang sesederhana mungkin atau sepraktis mungkin dengan biaya seminim mungkin. Hal ini disebabkan oleh jenis industri ini merupakan industri kecil kerajinan yang bermodal relatif kecil. Untuk mengefektifkan kegiatan Pengabdian kepada Masyarakat ini, maka khalayak sasaran ditujukan kepada para pengrajin genteng di Desa Gulun-Magetan.

Kegiatan ini bersifat pendidikan dan pelatihan serta perbaikan sarana penunjang produksi dengan aplikasi produksi untuk membantu pengrajin genteng dalam menjalankan usahanya sehingga diharapkan usaha ini dapat lebih berkembang dan dapat memberikan keuntungan yang memadai. Evaulasi kegiatan akan di lakukan setelah pembuatan alat pencetak genteng di tempat mitra. Pelatihan aplikasi produksi meliputi magaimana mengoprasikan alat penggiling, teknik memasukan pencetak genteng di dalam pencetak genteng yang di bawahnya.

Dari hasil uji coba mesin pembuatan pencetak genteng yang dilakukan pada industri kecil Desa Gulun Kabupaten Magetan dengan beberapa kali pengujian, diperoleh catatan sebagai berikut:

Dari sisi ipteks hal ini merupakan pengembangan peralatan teknologi tepat guna untuk menggiling atau menggilas tanah liat bahan baku genteng agar lebih cepat pemprosesan dan maksimal. Untuk meningkatkan efisiensi waktu produksi, maka pencetak genteng dibuat sedemikian rupa.

\section{Strategi Pengembangan Usaha Pengrajin Genteng}

Pengembangan usaha adalah jumlah seluruh kegiatan yang diorganisir oleh orang-orang yang berkecimpung dalam bidang perniagaan dan industri yang menyediakan barang dan jasa untuk kebutuhan mempertahankan dan memperbaiki standard serta kualitas hidupmereka. Pengembangan dilakukan agar industry yang dijalankan dapat tetap tumbuh, berkembang dan dapat diberdayakan, karena selain memberikan pendapatan terhadap pengrajin itu sendiri juga dapat membantu kesejahteraan masyarakat sekitar dengan menyediakan lapangan usaha. Oleh sebab itu perlu mengupayakan hal-hal sebagai berikut:

\section{Peningkatan akses pada asset produktif}

Dalam upaya pengembangan usaha kerajinan genteng untuk meningkatkan kesejahteraan pengrajin kendala utama yang dihadapi adalah masalah modal. Disamping masalah keterbatasan modal, juga terdapat keterbatasan dalam pengelolaan keuangan secara jelas.

Peran pembukuan keuangan sangat penting dalam upaya peningkatan pengelolaan dan pengalokasian keuangan secara baik, selain itu pembukuan keuangan atau laporan keuangan dibutuhkan dalam mengajukan pinjaman perbankan Manfaat laporan keuangan juga dapat melihat secara pasti tingkat keuntungan dan pengelolaan yang lain, jadi sebenarnya apabila dilakukanbisa menganalisis bagaimana menefisiensikan sumber daya yang dimiliki.

Masalah keterbatasan dalam meningkatkan modal menyebabkan industri kecil kerajinan genteng mengalami kesulitan dalam meningkatkan kapasitas produksi untuk memenuhi permintaan, adopsi peralatan modern untuk mendukung proses produksi, dan peningkatan jumlah tenaga kerja professional.

Peralatan modern untuk mendukung proses produksi atau teknologi merupakan salah satu sumber utama perubahan dengan adanya inovasi baru. Variabel ini mempengaruhi bahan baku, operasi, serta produk suatu usaha karena pada dasarnya perubahan teknologi dapat memberikan peluang besar untuk peningkatan hasil, mencapai efisiensi dan perubahan inovasi.

Teknologi yang terus berkembang memberikan peluang bagi keberadaan industri kecil kerajinan genteng. Dalam upaya mendorong pertumbuhan usaha produktif, untuk mengatasi kurangnya modal pada industi kecil, pemerintah telah melakukan usaha bantuan modal kredit dengan bunga rendah melalui Lembaga Keuangan baik Bank maupun Non Bank seperti: Kredit Usaha Rakyat (KUR), Corperate Social Responsibility (CSR), dan Kredit Ekonomi Kerakyatan (EKOR). 
Website : http://dayamas.unmermadiun.ac.id/index.php/dayamas

Apabila dimanfaatkan dengan baik, bantuan melalui perbankan seharusnya mampu membantu dalam hal permodalan, tetapi pengusaha industri kecil kerajinan genteng sebagian besar kurang memanfaatkannya. Sehingga berpengaruh terhadap peningkatan kapasitas dan alat pendukung proses produksi.

\section{Peningkatan akses pada pasar}

Dalam pengembangan usahanya setiap perusahan disarankan untuk tetap menjaga kualitas produk. Jumlah penduduk yang semakin meningkat, memungkinkan terjadinya permintaan genteng yang meningkat karena pola konsumsi masyarakat yang masih mengandalkan genteng sebagai atap rumah. Pangsa pasar yang masih cukup luas memberikan kesempatan bagi industri kecil kerajinan genteng di Desa Gulun untuk meningkatkan penjualanya dan melakukan penjualan produk yang sudah ada ke pasar yang baru.

Kondisi perekonomian yang semakin mendukung, pola konsumsi masyarakat terhadap genteng meningkat, dan jumlah penduduk yang semakin meningkat ini menjadi peluang bagi industri kecil kerajinan genteng. Kondisi tersebut akan memungkinkan banyaknya selera masyarakat yang semakin beragam dan berubah. Untuk dapat meningkatkan penjualan, memenuhi permintaan sesuai selera konsumen industri kecil kerajinan genteng memerlukan inovasi produk genteng. Pengembangan produk genteng bisa berupa dari corak dan bentuk yang semakin indah dengan disesuaikan kebutuhan masyarakat.

\section{Kewirausahaan atau Pelatihan}

Pemerintah perlu meningkatkan pelatihan bagi UKM baik dalam aspek kewiraswastaan, manajemen, administrasi dan pengetahuan serta keterampilannya dalam pengembangan usahanya. Disamping itu juga perlu diberi kesempatan untuk menerapkan hasil pelatihan dilapangan untuk mempraktekan teori. Pelaksanaan pelatihan dilakukan dengan tujuan meningkatkan profesionalisme berwirausaha, menumbuhkan jiwa kewirausahaan, meningkatkan kemampuan keterampilan dan penguasaan teknologi serta meningkatkan akses pasar dan perluasan pasar. Di masa yang akan datang diharapkan ada peluang lagi untuk industry kecil kerajinan genteng diberi pelatihan oleh dinas terkait seperti dinas Perindustrian dan Perdagangan, selain itu juga dari dinas Koperasi dan Usaha Mikro. Pelatihan dari Dinas terkait tentunya akan menjadi peluang bagi industri kecil kerajinan genteng di Kabupaten Magetan untuk pengembangan usahanya.

Berdasarkan upaya pengembangan diatas, diharapkan pengrajin mampu membuat usaha genteng semakin berkembang. Mampu mengidentifikasi setiap peluang usaha dengan menyeleksi dan mengkaji ulang peluang usaha yang menguntungkan, seperti memaksimalkan kekuatan faktor produksi dengan mengahasilkan produk sesuai permintaan konsumen baik dari segi kualitas, kuantitas dan kontinuitas agar dapat memberikan pelayanan yang baik kepada pelanggan, sistem manajemen usaha harus lebih baik agar dalam penyusunan rencana usaha dapat terorganisasi secara baik, serta mengantisipasi ancaman dari pesaing usaha.

Namun dengan adanya pengembangan menunjukkan banyak pengrajin yang mundur dengan berkurangnya jumlah usaha kerajinan genteng.

\section{IV.KESIMPULAN}

Setelah pelaksanaan pengabdian kepada masyarakat ini dapat disimpulkan hasil-hasil kegiatan sebagai berikut:

1. Pemahaman mitra tentang perlunya pengelolaan dan pemberdayaan manajemen usaha yang baik dan sehat perlu ditingkatkan

2. Dalam rangka mengembangkan usaha, perlu dilakukan pelatihan manajemen usaha yang professional.

3. Melakukan pendampingan dan pemasaran hasil produksi agar mampu bersaing dengan produk pesaing.

4. Memperkenalkan teknologi tepat guna (pencetak genteng pada masyarakat industri kecil), karena teknologi yang diberikan sangat sederhana dalam pengoperasiannya efektif dan efisien, sehingga dapat menghasilkan produk yang mampu berproduksi cepat baik kwalitas pencetak genteng dan kuantitas pencetak genteng.

\section{SARAN}

Saran ini khususnya ditujukan pada mitra kegiatan pengabdian kepada masyarakat, yaitu:

1. Hendaknya pemerintah daerah melalui Dinas Koperasi dan Usaha Mikro melakukan pembinaan secara berkala kepada para pengrajin genteng agar memiliki pengetahuan dan ketrampilan yang baik dalam mengelola usaha genteng.

2. Hendaknya perusahaan milik Negara dan perusahaan daerah memberikan bantuan permodalan dan pendampingan agar usaha para pengrajin genteng dapat berkembang pesat dan mampu meningkatkan kesejahteraan, yang nantinya dapat berpengaruh pada perekonomian daerah.

\section{VI.UCAPAN TERIMA KASIH}

Ucapan terima kasih disampaikan kepada berbagai pihak khususnya kepada Mitra pengabdian dan Dinas Koperasi dan Usaha Mikro Kabupaten Magetan yang telah memberikan ijin pelaksanaan pengabdian masyarakat dan meluangkan waktu untuk membantu kelancaran pelaksanaan pengabdian masyarakat. Tidak lupa terima kasih juga kami sampaikan kepada rekan-rekan 
Website : http://dayamas.unmermadiun.ac.id/index.php/dayamas

dosen yang telah memberikan saran-saran kritis demi kesempurnaan hasil penelitian ini. Demikian juga terima kasih disampaikan kepada Rektor Universitas Merdeka Madiun yang telah memberikan pendanaan dalam penelitian ini.

\section{DAFTAR PUSTAKA}

Abdullah, Maskur. 2005. Lilitan Masalah Usaha Mikro kecil, Menengah (UMKM) dan Kontroversi Kebijakan. Medan: Bitra Indonesia.

Anoraga, Panji. 2002. Koperasi, Kewirausahaan, dan Usaha Kecil. Jakarta: Rineka Cipta.

Harry Hikmat, 2001. Strategi Pemberdayaan Masyarakat, Edisi revisi, Penerbit Humaniora, Bandung.

Kasali, Rhenald dkk. 2012. Kewirausahaan. Hikmah : Jakarta.

M.Cholil Masyur, 1999. Sosiologi Masyarakat Kota dan Desa, Penerbit Usaha Nasional, Surabaya.

Prabowo, Hendro dan Wardoyo. 2003. Kinerja Lembaga Keuangan Mikro bagi Upaya Penguatan Usaha Mikro, Kecil, dan Menengah di Wilayah Jabotabek. Depok: Universitas Gunadarma.

Sudaryanto dan Hanim, Anifatul. 2002. Evaluasi kesiapan UKM Menyongsong Pasar Bebas Asean (AFTA) : Analisis Perspektif dan Tinjauan Teoritis. Jurnal Ekonomi Akuntansi dan Manajemen, Vol 1 No 2, Desember 2002.

Suryana, 2006. Kewirausahaan. Penerbit Salemba 4, Jakarta. 